\title{
FAKTOR-FAKTOR YANG MEMPENGARUHI PENGEMBANGAN DESA WISATA NGANGGRING SLEMAN
}

\author{
Anik Widiastuti \\ Program Studi Pendidikan IPS FIS UNY \\ anikwidiastuti@uny.ac.id \\ Anissa Siti Nurhayati \\ Program Studi Pendidikan IPS FIS UNY
}

\begin{abstract}
Intisari
Desa Wisata Nganggring merupakan desa wisata yang terdapat di Kabupaten Sleman yang termasuk dalam kategori tumbuh. Penelitian ini bertujuan untuk: (1) mengetahui faktor pendorong pengembangan Desa Wisata Nganggring; dan (2) mengetahui faktor penghambat pengembangan Desa Wisata Nganggring.

Penelitian ini merupakan penelitian studi kasus yang dilaksanakan pada bulan April-Oktober 2018. Subjek penelitian adalah pengurus desa wisata, dewan penasehat desa wisata, dan ketua koperasi desa wisata yang dipilih dengan teknik purposive sampling. Teknik pengumpulan data menggunakan wawancara dan observasi. Teknik analisis data menggunakan analisis interaktif Miles dan Huberman.

Hasil penelitian menunjukkan bahwa: (1) Faktor pendorong pengembangan Desa Wisata Nganggring dikategorikan menjadi dua yaitu faktor internal (berupa kesadaran dan kemauan masyarakat, banyaknya potensi yang ada baik potensi ekonomi maupun potensi lingkungan, serta terdapat banyak atraksi wisata), faktor eksternal (berupa dukungan dan bantuan dari Pemerintah Desa, Kabuapaten serta Provinsi); (2) Faktor penghambat pengembangan Desa Wisata Nganggring berupa keterbatasan SDM serta adanya konflik kepentingan antara anggota masyarakat serta pengurus desa wisata yang menghambat pelaksanaan program-program desa wisata.
\end{abstract}

Kata kunci: desa wisata, pengembangan

\section{PENDAHULUAN}

Pariwisata merupakan salah satu aspek yang dapat diandalkan sebagai sumber pendapatan bagi suatu negara. Dengan berkembangnya pariwisata tentu saja akan berdampak pada meningkatnya berbagai lapangan kerja sehingga dapat mengurangi jumlah pengangguran serta mengentaskan kemiskinan. Berdasarkan hal tersebut, pemerintah menggalakkan program wisata dengan berbagai promosi 
yang mengangkat destinasi-destinasi wisata yang memiliki keunggulan spot-spot untuk menarik wisatawan.

Tren berwisata dari tahun ke tahun mengalami perubahan. Banyak masyarakat yang saat ini lebih memilih untuk berwisata di tempat-tempat yang bukan mainstream. Hal itulah yang mendorong adanya pengembangan pariwisata di seluruh pelosok Indonesia. Pengembangan pariwisata juga menjadi perhatian pemerintah agar dapat menjadi sumber pemasukan bagi masyarakat daerah tujuan wisata. Pemerintah juga memberikan dukungan sarana prasana yang memadai untuk pengembangan desa wisata agar daerah tujuan wisata memiliki aksesibilitas yang tinggi.

Indonesia yang wilayahnya sangat luas, belum seluruhnya memiliki pola kekotaan, bahkan masih banyak yang memiliki pola kedesaan. Berdasarkan hal tersebut dapat kita simpulkan bahwa Indonesia masih banyak memiliki potensi desa-desa yang dapat dikembangkan menjadi daerah tujuan wisata, atau yang saat ini terkenal dengan sebutan desa wisata. Kepala Badan Pusat Statistik (BPS), Suhariyanto menyebut bahwa salah satu potensi unggulan desa atau kelurahan adalah melalui sektor wisata. Tercatat dari Potensi Desa (Podes) 2018 terdapat 1.734 desa wisata di seluruh Indonesia. Desa wisata tersebut tersebar di masingmasing kepulauan. Di mana Pulau Jawa - Bali menempati posisi paling tinggi dengan 857 desa wisata. Kemudian di ikuti dengan Sumatera sebanyak 355 desa, Nusa Tenggara 189 desa, Kalimantan 117 desa. Selain itu, Pulau Sulawesi juga tercatat sebesar 119 desa wisata, Papua 74 desa, dan Maluku sebanyak 23 desa. (Merdeka.com, 2018). Data ini menunjukkan banyaknya potensi pariwisata yang ada di Indonesia yang tersebar di seluruh pulau. Pemerintahpun menaruh perhatian yang cukup tinggi terhadap potensi yang dimiliki masing-masing daerah dengan memberikan dukungan pengembangan sampai seluruh pelosok negeri.

Melihat potensi yang ada serta dukungan pemerintah yang sangat besar dalam pengembangan desa wisata, harusnya kesempatan ini ditangkap oleh seluruh pemerintah desa agar dapat mengembangkan desanya ke arah kemandirian. Tujuan dari pengembangan desa wisata relevan dengan RPJMN yaitu berusaha menurunkan jumlah desa tertinggal agar dapat menjadi desa mandiri. Lingga \& 
Setiawan dalam kompas.com 2018 menyebutkan bahwa melalui Podes (Potensi Desa) 2018 desa tertinggal berkurang sebesar 6.518, diperoh data desa tertinggal sebanyak 14.461 desa (19,17 persen), desa berkembang sebanyak 55.369 desa (73,4 persen), dan desa mandiri sebanyak 5.606 desa (7,43 persen). Berkurangnya jumlah desa tertinggal menjadi salah satu aspek perhatian dalam IPD (Indeks Pembangunan Desa) sehingga banyak program-program pemerintah serta kucuran dana yang ditujukan untuk pengembangan desa wisata.

Salah satu Kabupaten yang memiliki cukup banyak desa wisata adalah Kabupaten Sleman yaitu sebanyak 31 desa wisata. Di Kabupaten Sleman, terdapat Kecamatan Turi yang memiliki desa wisata dengan jumlah terbanyak yaitu 9 desa wisata yang terdiri dari 4 desa wisata dalam kategori tumbuh, 3 desa wisata dalam kategori berkembang dan 2 desa wisata dalam kategori mandiri. Desa wisata yang termasuk dalam kategori tumbuh inilah yang perlu melakukan berbagai upaya agar dapat menjadi desa wisata yang mandiri. Hal ini menjadi tanggung jawab pengelola desa wisata untuk dapat melakukan terobosan-terobosan ke arah kemajuan. Salah satu desa wisata yang termasuk dalam kategori tumbuh atau embrio yaitu desa wisata Nganggring. Desa wisata Nganggring memiliki beberapa keunikan baik dari segi alam maupun budaya. Keunikan yang ada di Nganggring dikembangkan dengan konsep wisata edukasi. Perhatian pemerintah dalam pengembangan desa wisata Nganggring cukup banyak seperti pelatihan-pelatihan dan juga termasuk bantuan dana pengembangan.

Berdasar hal di atas, seharusnya desa wisata Nganggring dapat tumbuh dan berkembang dengan cepat, akan tetapi pengembangan desa wisata Nganggring ternyata tidak semudah yang dibayangkan. Terdapat berbagai faktor yang berpengaruh dalam pengembangan desa wisata Nganggring yang akan dibahas dalam artikel ini.

\section{Pariwisata}

Yoeti (2010: 46-47) menjelaskan bahwa kata pariwisata berasal dari bahasa Sansekerta yakni pari yang artinya banyak, berkali-kali, berulangkali, berputarputar atau lengkap dan wisata yang berarti perjalanan, maka pariwisata diartikan 
sebagai perjalanan dari suatu tempat ke tempat lain yang dilakukan berulang kali atau berkeliling. Hunziker \& Kraft (Muljadi \& Warman, 2009: 9) mendefinisikan pariwisata sebagai keseluruhan hubungan dan gejala-gejala yang timbul dari adanya orang asing di mana perjalanannya tidak untuk bertempat tinggal menetap dan tidak ada hubungannya dengan kegiatan mencari nafkah.

Sammeng (2001: 30) menyatakan bahwa daya tarik atau atraksi wisata adalah segala sesuatu yang menarik sehingga menyebabkan seseorang berkunjung. Daya tarik wisata dapat dibedakan menjadi tiga kelompok, yaitu objek wisata alam, budaya, dan buatan. Objek wisata alam meliputi pemandangan alam, flora, fauna, kawasan lindung, cagar alam, dan lain-lain. Objek wisata budaya merupakan hasil cipta manusia di masa lampau, sedangkan objek wisata buatan merupakan hasil rekayasa manusia saat ini.

Karyono (1997: 74-76) menyebutkan bahwa fasilitas wisata dibagi dua, yakni prasarana dan sarana wisata. Prasarana atau infrastruktur adalah semua fasilitas yang memungkinkan proses pemenuhan kebutuhan menjadi lancar. Prasarana wisata diperuntukkan bagi wisatawan, meliputi tempat penginapan, tempat dan kantor informasi, tempat promosi, tempat-tempat rekreasi, dan sport. Sarana wisata adalah perusahaan-perusahaan yang memberikan pelayanan kepada wisatawan, baik secara langsung maupun tidak langsung. Sarana kepariwisataan dapat dibagi menjadi tiga bagian, yaitu: sarana pokok kepariwisataan (travel agent dan tour operator, perusaahaan angkutan wisata, hotel atau penginapan, rumah makan, dan atraksi wisata); sarana pelengkap kepariwisataan (sarana olahraga dan sarana ketangkasan); dan sarana penunjang kepariwisataan (club, steam baths, dan casinos).

\section{Desa Wisata}

Menurut Asyari (2015: 2-3) yang dimaksud dengan desa wisata adalah sebuah desa yang hidup mandiri dengan potensi yang dimilikinya dapat dijual sebagai atraksi daya tarik wisata tanpa melibatkan investor. Nurdiyansah (2014: 70) menjelaskan bahwa desa wisata adalah suatu pendekatan pengembangan pariwisata di mana elemen-elemen pengembangan wisata (atraksi, akomodasi, trasnportasi, 
elemen kelembagaan/pengelola, serta infrastruktur dan fasilitas layanan lainnya) memiliki integrasi dan harmonisasi dengan kehidupan masyarakat lokal atau desa dan aspek fisik kawasan suatu desa.

Dinas Pariwisata Daerah Istimewa Yogyakarta (2014: 2- 6) menjelaskan tipologi desa wisata didasarkan atas karakteristik sumber daya dan keunikan yang dimilikinya dapat dikelompokkan ke dalam empat kategori yaitu : 1) Desa wisata berbasis keunikan sumber daya lokal (adat, tradisi kehidupan masyarakat, artefak, atau budaya) sebagai daya tarik wisata utama; 2) Desa wisata berbasis keunikan sumber daya alam sebagai daya tarik utama (pegunungan, agro atau perkebunan dan pertanian, pesisir pantai); 3) Desa wisata berbasis perpaduan keunikan sumber daya budaya dan alam sebagai daya tarik utama; dan 4) Desa wisata berbasis keunikan aktivitas ekonomi kreatif (industri kerajinan dan kesenian) sebagai daya tarik wisata utama.

Berdasarkan tingkat perkembangannya, Simanungkalit dkk. (2016: 20-21) membagi desa wisata menjadi tiga kategori yaitu:

1) Desa wisata embrio : desa yang mempunyai potensi wisata yang dapat dikembangkan menjadi desa wisata dan sudah mulai ada gerakan masyarakat atau desa untuk mengelolanya menjadi desa wisata;

2) Desa wisata berkembang: desa wisata embrio yang sudah dikelola oleh masyarakat dan pemerintah desa, sudah ada swadaya masyarakat atau desa untuk pengelolaannya, sudah mulai melaksanakan promosi dan sudah ada wisatawan yang mulai tertarik untuk berkunjung, dan;

3) Desa wisata maju: desa wisata yang sudah berkembang dengan adanya kunjungan wisatawan secara kontinu dan dikelola secara profesional dengan terbentuknya forum pengelola, seperti Koperasi atau Badan Usaha Milik Desa (BUMDes), serta sudah mampu melakukan promosi daan pemasaran dengan baik.

Pengembangan desa wisata dapat dilakukan melalui berbagai cara sebagaimana dinyatakan Gumelar \& Putra dalam Zakaria \& Suprihardjo (2014: 247): memanfaatkan sarana prasarana masyarakat setempat, menguntungkan masyarakat setempat, skala kecil, melibatkan masyarakat setempat, menerapkan 
produk wisata pedesaan, terintegrasi dengan masyarakat, menawarkan berbagai atraksi khas, akomodasi berciri khas desa setempat. Desa wisata yang dikembangkan seharusnya memberikan manfaat bagi masyarakat setempat dan memiliki atraksi serta akomodasi yang khas dari desa tersebut.

Dalam pengembangan desa wisata diperlukan partisipasi aktif dan positif dari masyarakat sebagaimana dikemukakan oleh Dewi, Fandeli \& Baiquni (2013: 134), partisipasi masyarakat dalam pembangunan merupakan hal yang penting karena masyarakatlah yang paling tahu apa yang dibutuhkan sehingga partisipasi akan melibatkan masyarakat dalam seluruh tahapan pengembangan yang pada akhirnya masyarakat dapat berpartisipasi aktif dalam pelaksanaan dan pengawasan.

\section{METODE}

Metode penelitian yang digunakan adalah studi kasus (case study). Penelitian ini menggunakan metode studi kasus dengan maksud mendeskripsikan hasil penelitian dan berusaha menemukan gambaran menyeluruh mengenai suatu keadaan. Menurut Yin (2014: 18), studi kasus merupakan suatu inkuiri empiris yang menyelidiki fenomena di dalam konteks kehidupan nyata, bilamana batas-batas antara fenomena dan konteks tak tampak tegas, dan di mana multisumber bukti dimanfaatkan. Subjek dalam penelitian ini diambil berdasarkan sampel yang telah ditentukan yaitu purposive sampling. Subjek penelitian ini adalah pengurus desa wisata, dewan penasehat desa wisata, dan ketua koperasi desa wisata (ketua Koperasi Tani Mandiri). Jenis data yang dikumpulkan dan digunakan dalam penelitian ini yaitu data kualitatif. Penelitian ini menggunakan sumber data primer yang diperoleh dari wawancara dan observasi. Pemeriksaan keabsahan data dalam penelitian ini dilakukan dengan triangulasi sumber data. Teknik analisis data yang digunakan adalah teknik analisis interaktif Milles \& Hubberman (2014: 20) yang meliputi tahap pengumpulan data, reduksi data, penyajian data, dan penarikan kesimpulan. 


\section{HASIL PENELITIAN DAN PEMBAHASAN}

Terdapat beberapa faktor yang mempengaruhi pengembangan Desa Wisata Nganggring. Faktor tersebut antara lain:

a. Faktor Pendorong

Terdapat faktor internal dan eksternal yang mendorong pengembangan Desa Wisata Nganggring.

1. Faktor internal berupa kesadaran dan kemauan masyarakat setempat untuk mengembangkan desa wisata. Faktor internal lainnya yaitu banyaknya potensi yang ada di Desa Wisata Nganggring berupa potensi ekonomi maupun potensi lingkungan. Selain itu didukung juga adanya peternakan kambing yang sejak awal memang sudah banyak pengunjungnya, serta terdapat banyak atraksi wisata.

2. Faktor eksternal berasal dari pihak luar, yaitu dukungan dan bantuan dari pemerintah desa, pemerintah kabupaten (Dinas Pariwisata Kabupaten Sleman), bahkan provinsi (Dinas Pariwisata Provinsi DIY) yang sangat berperan terhadap kemajuan Desa Wisata Nganggring.

b. Faktor Penghambat

Faktor penghambat pengembangan Desa Wisata Nganggring adalah keterbatasan SDM karena banyak yang bekerja maupun bersekolah, bahkan ada yang memang belum mau terlibat dalam kepengurusan desa wisata. Faktor lain yang menghambat pengembangan Desa Wisata Nganggring adalah terjadinya konflik. Konflik yang ada berupa perbedaan persepsi antar anggota masyarakat, benturan kepentingan antara anggota masyarakat serta pengurus desa wisata yang menghambat pelaksanaan program-program desa wisata. Konflik adalah hal umum terjadi dalam suatu kelompok. Konflik dapat bersifat membangun maupun merusak. Terjadinya konflik dapat menurunkan semangat pengelola Desa Wisata Nganggring dalam melaksanakan program.

Adanya berbagai faktor yang menghambat pengembangan desa wisata seperti yang telah diungkapkan di atas perlu dicari penyelesaiannya. Pengelola Desa Wisata Nganggring melakukan berbagai upaya untuk mengatasi permasalahan yang menghambat pengembangan desa wisata. Adapun upaya yang dilakukan yaitu: 
1) Musyawarah. Musyawarah dilakukan untuk mencapai mufakat. Musyawarah memungkinkan setiap orang menyampaikan pendapatnya yang pada akhirnya akan diambil kesepakatan bersama.

2) Pendekatan personal. Pendekatan personal dilakukan untuk merangkul masyarakat agar mau terlibat dalam pengembangan Desa Wisata Nganggring. Pendekatan personal akan menyebabkan seseorang merasa dihargai dan akan berdampak pada kinerja yang maksimal

3) Transparansi sitem pengelolaan. Transparansi sistem pengelolaan dilakukan dengan tujuan menghindari kecemburuan para pengelola, hal ini biasa berkaitan dengan honorarium pekerja. Pemberian honor dilakukan setelah pelaksanaan kegiatan. Jumlah honor disesuaikan dengan kinerja yang telah dilakukan serta dilakukan dengan transparan untuk menghindari adanya kecurigaan antar pihak.

4) Pemaksaan. Pemaksaan merupakan upaya yang dilakukan ketika upaya lainnya tidak mampu menyelesaikan permasalahan. Pengurus Desa Wisata Nganggring memiliki aturan sebagai dasar pelaksanaan pengembangan desa wisata. Aturan tersebut harus ditaati dan dilaksanakan oleh seluruh elemen yang terlibat dalam pengembangan desa wisata.

\section{SIMPULAN}

Pengembangan desa wisata memerlukan dukungan dari berbagai pihak agar dapat menjadi andalan pendapatan bagi masyarakat di Desa wisata. Dalam pengembangan desa wisata terdapat berbagai factor yang berpengaruh baik berupa factor pendorong maupun factor penghambat. Sebagaimana halnya factor-faktor yang mempengaruhi pengembangan desa wisata yang terdapat di Desa Wisata Nganggring. Faktor pendorong pengembangan desa wisata dapat dijadikan kekuatan dalam pengembangan desa wisata tersebut akan tetapi factor penghambat pengembangan desa wisata dapat diantisipasi dan dapat dikelola agar dapat diubah menjadi peluang pengembangan desa wisata. 


\section{DAFTAR PUSTAKA}

Dewi, M.H.U; Faneli, C.; Baiquni, M. (2013). Pengembangan Desa Wisata Berbasis Partisipasi Masyarakat Lokal di Desa Wisata Jatiluwih Tabanan Bali. Jurnal Kawistara Vol. 3, No. 2, Hal 129-139.

Dinas Pariwisata Daerah Istimewa Yogyakarta. (2014). Laporan Akhir Kajian Pengembangan Desa Wisata di DIY. Yogyakarta : Dinas Pariwisata DIY diunduh pada 19 Februari 2018 pukul 08.35 WIB dari http://visitingjogja.web.id/assets/uploads/files/bank_data/Lap_Akhir_Kajian_P engembangan_Desa_Wisata_DIY_08092016081709.pdf

Putra. (2018). Data BPS: Indonesia Miliki 1.734 Desa Wisata. Diakses dari https://www.merdeka.com/uang/data-bps-indonesia-miliki-1734-desawisata.html pada hari Jumat tanggal 1 Februari 2018 pukul 09.33 WIB

Karyono, H. A. (1997). Kepariwisataan. Jakarta: PT Grasindo.

Lingga, M.A. \& Setiawan, S.R.D. "BPS: Jumlah Desa Tertinggal Berkurang 6.518 Desa ", https://ekonomi.kompas.com/read/2018/12/10/133742026/bps-jumlahdesa-tertinggal-berkurang-6518-desa. Diakses pada hari Senin tanggal 4 Februari 2018 pukul 08.55 WIB

Miles, M. B \& Huberman, A. M. (2014). Analisis Data Kualitatif: Buku Sumber Tentang Metode-Metode Baru (Terjemahan Tjejep Rohendi Rohidi). Jakarta: UI-Press. Mill, R.C. (2000). Tourism The International Business (Edisi Bahasa Indonesia). Jakarta: PT RajaGrafindo Persada

Muljadi, A. J. \& Warman, A. (2014). Kepariwisataan dan Perjalanan. Jakarta: PT Raja Grafindo Persada

Nurdiyansah. (2014). Peluang dan Tantangan Pariwisata Indonesia. Bandung: Alfabeta

Sammeng, A. M. (2001). Cakrawala Pariwisata. Jakarta: Balai Pustaka.

Simanungkalit, dkk. (2016). Buku Panduan Pengembangan Desa Wisata Hijau. Jakarta: Asisten Deputi Urusan Ketenagalistrikan dan Aneka Usaha Kementerian Koperasi dan UKM Republik Indonesia. Diunduh pada 22 Januari 2018 pukul 06.19 WIB dari http://kemenpar.go.id/userfiles/LAPORAN\%20KINERJA\%20KEMENPAR\% 202016_FINAL.pdf

Yin, R.K. (2014). Studi Kasus: Desain dan Metode. Jakarta: PT RajaGrafindo Persada 
Yoeti, O.A. (2010). Dasar-dasar Pengertian Hospitaliti dan Pariwisata.

Bandung: Alumni

Zakaria, F. \& Suprihardjo, R.D. (2014). Konsep Pengembangan Kawasan Desa Wisata di Desa Bandungan Kecamatan Pakong Kabuapaten Pamekasan. Jurnal Teknik Pomits Vol. 3 No. 2, hal. 245-249 